\title{
МЕНАЏИРАЊЕ СО ЧОВЕЧКИ РЕСУРСИ
}

\section{Апстракт}

Функцијата на менацирането со човечките ресурси е да им обезбеди на вработените развиване на нивните способности преку систем на менаиментски постапки, да обезбеди развиване на нивните способности преку селекцциа и регрутација до промоција и напредни бенефити, компензацчија, градене кариера и сл. Функцијата, во таа смисла, е да се промовира ефикасен менацмент-систем преку кој ке се постигнат долгорочните цчели и планови на организацијата. Исто како и кај компаниите од реалниот сектор, така и кај меначментот со човечки ресурси главната целе да создаде можност за развој на човечките ресурси како клучен фактор за напредок на организацијата.

Целите на менаиментот со човечки ресурси вклучуваат ефикасно спроведуванье утврдена политика и координациија на човечки ресурси како на национално така и на локално ниво на практикуване на власта. Како главни сегменти од ланецот на меначиране со човечки ресурси се: селекциијата, работните односи и мотивацијата како стожерни фактори, потоа дијагностициранье на потребите на организацијата, консументите, но и на потребите и предизиuзите на вработените.

Клучни зборови: човечки ресурси, меначиране/меначиране, стратешко планиранье, регрутациија, работни односи, обуки, развој и кариера и сл.

\section{Вовед}

Работните односи се однесуваат на систем во кој работодавачите, вработените и нивните претставници, и, директно или индиректно и владата соработуваат при воспоставувањето на основните правила за менаџирање со работните соодноси.

Овој термин се користи во врска со најраздични форми на работничкото учество, индивидуалниот однос помеѓу работодавачот и вработениот, кој однос е склучен со потпишувањето на договорот за работа. Системот на работни односи во себе инкорпорира и социјални (општествени) вредности како што се: слобода на здружување, чувство на групна солидарност и сл.

При анализирањето на односот помеѓу менаџерот со човечки ресурси и работничките односи, потребно е да се познаваат основните заложби при воспоставувањето и развивањето на односите работник - работни за- 
дачи, работник - работник, работник - менаџер и работник - организација и работник - синдикат.

Најглавните заложби при воспоставувањето на содидни работни односи на работното место се:

Крајна цел на менацерот со човечки ресурси во системот на работни односи е создавање висок капацитет на организацијата од раздични профили на вработени, односно човечки ресурси (способни работници) на организацијата, за ефикасна испорака на подитики преточени во сервиси како квадитетен производ до граѓаните и градење сопствен човечки капитал составен од добри работници и поддржани таленти. Тоа го постигнува преку:

1. Хармонични работни односи - добриот менаџер со човечки ресурси е посветен на интересите на организацијата но и на излегување во пресрет на интересите и очекувањата на вработените.

2. Одредување адекватни правила и услови на вработувањето, и тоа во интерес на работодавачот, но и на работникот и на општеството во целост. Овие услови најчесто се постигнати со консензус на општествените парнери: владата, работодавачот и работничките организации (синдикати).

3. Воспоставување механизми на комуникација, интеракција работник - работник, работник - претпоставен, менаџер со менаџер, преку прифатени и воспоставени механизми и процедури за консултации и соработка со цел да се избегнат иди надминат конфдикти и тековни проблеми на работното место и да се постигне консензус за работничките политики на национално ниво. Таков пример е со утврдување на работно време, прекувремена работа, минимална плата, годишен одмор и сл.

4. Избегнување кршење на веќе воспоставени правила и механизми за заштита на работните односи.

5. Градење и примена на системи за обезбедување транспарентност, вклученост и мотивираност на сите заинтересирани за развој интересни групи.

Работните односи не се однесуваат само во сферата на колективната работничката законска заштита. Во праксата, работните односите најчесто се дел од обврската на менаџментот со човечки ресурси и се присутни од регрутацијата, градење тимови, комуникација и кооперација па сѐ до развојот на кариера на поедини работници (Bach, S. and Edwards, R.M, 2012).

Значи, менаиментот на човечки ресурси во својата суштина се состои токму во следните фази: да се идентификуваат чувствата на вработените во однос на неисполнетите потреби ито ги чувствуваат, согледувате на кој начин да се задоволат потребите на вработените, селектиране цели и заеднички договор со вработениот на кој начин истите цели да се реализираат, ито е важно бидејки чувството за потреба од мотивација е лично и во колку навремено не се соработува со вработениот, тој самиот ќе ги постави своите цุели, ито пак 
може да се разликуваат од целите на политиката на работното место, потоа, извриуваюе на работата, последицииефекти од извриената работа и награда односно казнуванье.

Менацерот е тој кој е одговорен за развој на човечките ресурси, задолжен да ги развива нивните потенцијали и вештините, работните способности и нивното максимално и правилно организирање и искористување. Најчесто тој е одговорен за спроведување на истражувањата, мерење на работниот придонес и квалитетот, користење на бенефициите, спорови околу плата, соработка со синдикати, конфдикти и спроведување дисциплински постапки и сл. Менаџерот за цело време е во соработка со другите претпоставени, менаџери, менаџери на сектори и сл. а во согласност со подитиките и стратегиите и стратешките планирања на ниво на организација.

\section{Воведување во работата - индуктивни програми за социјадизација}

Воведувањето на нововработениот во работата или на вработениот кој е распореден на ново работно место започнува со поставувањето на најглавната цел од оваа фаза - зајакнуватьето на самодовербата на вработениот во новата организација иди во новата работна средина. Тоа се постигнува со намалувањето на стравувањето кај работникот дека нема да може да ја извршува работата и да се вклопи во колективот. Тоа пак најдиректно може да води кон одбивање на културата и политиката на организацијата од страна на работникот.

И современата пракса во менаџирањето со човечки ресурси укажува дека успешната социјализација - воведувањето во работата е многу важен момент кој може да се рефлектира долг период како во позитивен така и во негативен контекст. Затоа, за да се избегне негативниот контекст при воведувањето на нововработените во работната средина и задачи, се изработуваат посебни т.н. индуктивни програми најчесто од два до три дена, кога треба новиот вработен да се претстави на претпоставените и останатите вработени. За таа цел однапред се договаарат термини со другите менаџери на сектори, доколку карактерот на работата на нововработениот е поврзана со други сектори, а потоа нововработениот се запознава со работното место, колегите и подитиката на колективот и организацијата на начин што се посочуваат неговите способности во контекст со работните задачи.

Следното што се сака да се постигне во фазата на воведување е генерирање ставови кон организацијата и менаџерската структура внатре во неа и однесувањето на работникот. Доколку уште во најраната фаза на воведување во работата, работникот почне да гради позитивни ставови кон работната околината и самата работа, ваквото негово однесување ќе продолжи да се развива низ целиот негов работен век, а нововработениот ќе се развие во ценет работник и колега. Овие ставови треба да вдијаат на работникот да го приспособи своето однесување со цел да ја постигне 
како неговата цел така и целите и политиките на организацијата. Следен пример би можел да биде и волонтерското работење, кое пак најмногу се спроведува еднаш месечно и со одредени цели.

Процесот на воведување нововработен има и друга димензија, бидејќ́ тој придонесува да ги потсети останатите вработени од највисоката до најниската скала во хиерархијата дека и тие биле некогаш во позиција на новиот колега и дека исто така имале свои амбиции и цели. На тој начин во овој процес имаат можност да се преиспитаат што и како постигнале во изминатиот работен век во овој колектив.

\section{Работна перформанса}

Оваа фаза од менаџментот со човечките ресурси до неодамна исклучиво се однесуваше за приватниот сектор и реалните компании, каде што основната цел е да се подобри продуктивноста на компанијата преку менаџирање со ефикасно извршување на работата. Сега во ЕУ целокупните реформи се засновуваат токму кон конкурентно ориентирана компанија, а тоа се изведува со добра изведба односно учинок при работата ${ }^{1}$.

Започнува со начинот на размислување ориентирано кон изведбата и учинокот од изведбата. Потоа следува фазата на воспоставување разбирливи и утврдени стандарди на изведба, следење и обезбедување повратни информации и проценка. первизира.

Потоа се изработува план со почеток и крај на периодот кој се су-

Очекувань за учинок се основата за процена на работната перформанса. Стандардите ја зацртуваат основната динија за мерење на изведбата. Преку стандардите се обезбедува фидбек кој ќе го опише јазот помеѓу очекуваната и актуелната изведба.

Добропоставените стандарди се објективна основа за проценување на начинот на извршување на работите, обезбедуваат вработените да се запознаат со прифатливите и неприфатливите резултати, вработените се задоволни кога знаат дека задачите се изведени добро, новите вработени преку стандардите се информираат за очекувањата околу извршувањето на работата.

Основните термини преку кои се опишува изведбата се:

- Квантитет - се изразува колку работа е потребно да биде извршена во одреден период.

- Квалитет - со овој термин се опишува колку добро една работа е завршена.

- Временска рамка - претставува одредено време (од - до) една работа треба да се заврши.

\footnotetext{
${ }^{1}$ www.oshr.nc.gov
} 
- Ефективно користене на ресурсите - се користи кога изведувањето на работата се посматра преку ефективното користење ресурси: заштеда на пари, отпадоци и сл.

- Начин на ангажиранье - се опишуваат условите кога дичното однесување на работникот влијае врз изведбата на работата, на пр. еден работник ја завршува својата работа квалитетно и пред време или пак, ситуацијата е таква што во моментот на мерење не е оптоварен со работа и своето работно време го користи да им помогне на колегите, а со тоа 100 \% од работното време е работно ангажиран.

- Начин на работа - ги опишува условите кога однесувањето на службеникот вдијае на работата на другите (ангажира други службеници за да се заврши поставената задача).

- Работа според пропишани процедури и рутини - овој модул се користи кога за една работа е пропишата една рутина па се мери колку службеникот успева да ја заврши работата и со кој квалитет без притоа да издезе надвор од рутините.

\section{Начини на мониторинг на изведбата на работата}

Најчести начини на ефективен мониторинг и верификација на изведбата се:

- Директна опсервација;

- Специфични резултати (чувствителни докази кои можат да бидат подложни на ревизија, а службеникот притоа да не биде присутен.

- Поднесување извештаи и снимања, како што се извештај за редовност, безбедност при работењето, финансиски продуктивно работење и сл.

- Собирање конструктивни критики за работата на службеникот (позитивни иди негативни).

\section{Повратна информација - фидбек}

Вработените имаат потреба како за примање така и за пренесување важни информации, сѐ со цел да се зајакне нивниот придонес кон успешноста на организацијата што пак води кон зголемени бенефиции за нив. Ваквите пренесувања на информации можат да се применат во ситуација кога резултатите од работата не се според очекувањата, а причините за тоа или се малку познати и нестабилни или воопшто не се познати.

Повратната информација, во понатамошниот текст „фидбек“, е потребно да биде добро концептирана а вработените да бидат обучени како најдобро да разменуваат конкретни информации. Фидбекот се раздикува од стандардната комуникација бидејќи најтесно е поврзан со разбирањето 


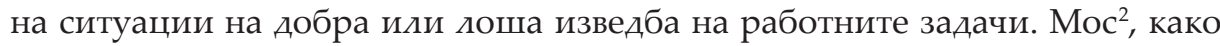
дел од истражувачки тим, дал детален опис за поставување теоретски основи за стратешки пристапи за менаџирање со фидбекот. Теоријата се состои во тоа што се објаснува како вработените гледаат на својата работа (добро извршена или лошо извршена, за да потоа ги споделат своите впечатоци со својот супервизор и ја посочат добрата изведба.

Најдиректната корист е зголемување на нивната способност за градирање на својата и на работата на другите, е да се подобри нивната дична одговорност и да се создадат можности да се реадизираат нивните индивидуални, групни и колективни посакувани бенефити. Вработените се оспособуваат критички да се осврнат на своите резултати на работа, евентуално да изнесат некои околности, објективни и субјективни кои според нив влијаеле за таквата реализација на своите работни задачи. Самите поставуваат долен праг на изведба и праќаат и примаат (разменуваат) информации со својот претпоставен и со менаџерот за човечки ресурси како да ја подобрат својата изведба и да го достигнат и престигнат долниот праг на бараната изведба за да се подобри нивната изведба. Или, како да се задржи добрата изведба и да се подобри. Фидбекот исто така се однесува и на реакцијата на вработените околу дадени однесувања и ситуации во организацијата, и многу често за нивните очекувани бенефити односно пенади.

Овој пристап овозможува да не се повредат егата на вработените преку навреди и казни, но да се разбере ситуацијата и окодностите од сите вклучени страни и заеднички да се постават стратешки краткорочни цели и методи за нивно остварување.

Праксата покажува дека со правилно изведен фидбек се надминува најчестата ситуација вработените со лоша изведба да одбиваат комуникација со нивните претпоставени, а нивната негативна енергија да ја лоцираат на работата која ја вршат, корисниците на нивните услуги и кон самата организација во која се вработени.

Ефикасното менаџирање со фидбекот е најдобро да се изведе од менаџерот за човечки ресурси бидејќи вработените истиот го прифаќаат како супервизор кој може да им помогне, но не може да ги казни бидејќи за тоа е надлежен нивниот директен претпоставен. Менаџерот овде има улога да им ја објасни ситуацијата, но притоа да отвори двонасочни канали на комуникација. Со него вработените дискутираат за личните причини за својата слаба изведба, се учат да бидат самокритични при самооценувањето, но и да бидат објективни во врска со условите, со разочараноста, со несоодветни и наметнати прагови на изведба и сл.

За да функционира фидбекот, потребно е менаџерот со човечки ресурси да воспостави јасна процедура и да вклучи лица во реализација на фидбекот (прибирање, давање и евалуација на податоци). Фидбекот може

${ }^{2}$ Sherry E. Moss and Juan I. Sanchez, "Are your employees avoiding you? Managerial strategies for closing the feedback gap", 2004, Academy of Management Executive, 2004, Vol. 18, No. 1 
да биде во писмена форма, што најчесто се применува во погодеми колективи, каде прашањата се од полуотворен или отворен тип, и директна форма, која пак се покажува најефикасна бидејќи се воспоставува однос на доверба и соработка, дури и партнерство помеѓу вработениот и менаџерот за човечки ресурси или неговиот претставник. Вкупниот резултат е што вработените стануваат многу пообјективни за постојната ситуација и развиваат чувство на партнерство со претпоставените за подобрување на дичните и на резултатите на организацијата. Ефектот е што вработениот се враќа во стандарден однос кон своето работно место, поточно, се помирува и се чувствува мотивиран и одговорен да ја подобри својата изведба очекувајќ́ договорени бенефити и стимулации. Фидбекот може да се третира и како двонасочно подучување. Кај обуките се поистоветува со евалуација на обуките од учесниците.

Од шематскиот приказ на кругот на одговорностите на менаџерот, се гледа дека менаџментот започнува со поставување јасни цели, потоа мерење на изведбата, добивање повратни информации на резултатите и одредување стимулативни наградувања засновани на нив, и на крајот, евалуација на поставените цели, на активностите кои водат до нивно остварување и на продуктите. Кругот се затвора со повторно поставување на целите.

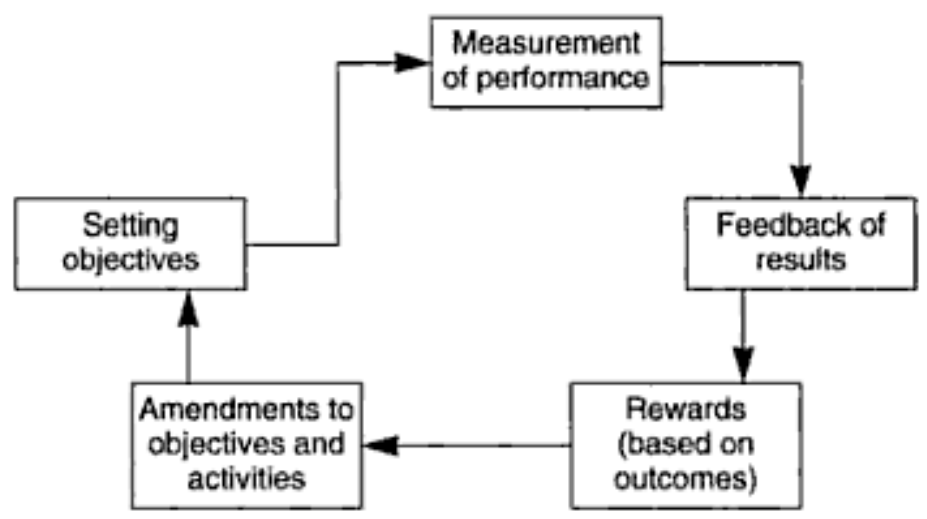

Figure 4.1 The performance management cycle

Слика бр.1 Поставување круг на одговорностите на менаџерот ${ }^{3}$

3 "Performance Management Cycle". University of California, Berkley, Center for Organizational and Workspace Effectiveness, https://dl.icdst.org/pdfs/files/08dca929258df3c1ee9a1f7be2598405.pdf 


\section{Тренинзи и оценувања/евахуација}

Најдоброто тренирање (подучување) се случува кога во дискусија се вклучени не повеќе од два аспекта од ланецот на работните задачи. На тој начин се зајакнува самодовербата и расте мотивацијата на вработениот како професионадно одговорна дичност. Овде, за раздика од другите системи на анализа на работите, вработениот чувствува дека има поддршка од претпоставениот во својот прогрес.

Тренирањето најчесто се применува кога е потребно да се сврти внимание на некои конкретни аспекти од работата на вработениот. Успешно тренирање е она кога постои фидбек од останатите вработени, за да се анализираат детално успешните изведби на вработените исто како и оние кои не се успешни и да се споредат, да му се посочат на службеникот алтернативни решенија, работникот пред проценувањето да биде навреме посоветуван и да му биде објаснето што и како ќе се проценува и да се има согласност од него, со што се обезбедува интерактивна улога. Добрата пракса покажува дека документирањето од сесиите може одлично да послужи како пример за следна сесија.

Најуспешни се оние тренинзи кога службеникот има доверба во тренерот а нивната комуникација е солидна.

Евалуациијата на работата е дел од процесот на менаџментот со човечки ресурси и овозможува одлична можност да се изврши евалуација на досегашната работа и тоа колку е задоволителна работата на еден работник. Посебно оценувањето е важно да биде согледано при стратешкото и развојното планирање. Тоа треба да го сумаризира досегашното залагање и квалитетот на работникот преку целиот период на оценување (обично една година) и не треба да биде третирано како дел од процесот на дисциплинирање на работникот.

Целите на оценувањето на работата се:

- Да му се помогне на службеникот да има позитивен однос кон својата работа;

- Да се мотивира да биде заинтересиран да работи добро и да биде спремен да ги развива своите перформанси;

- Да се добие конструктивен фидбек;

- Службеникот да биде вкдучен во развојниот процес.

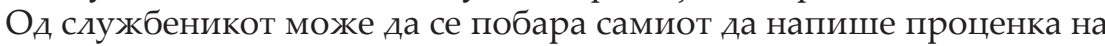
својата работа со тоа што ќе му се зададе определен прашалник или пак насоки како да ја изврши самоевалуацијата. Има многу техники за подготовка на оценувањето, но обично кај сите се подготвува шема на точки по кои ќe се оценува работата, на пр. опис на работата и тежина на работата, стандарди за извршување на работата воспоставени кога работникот ја прифатил истата, примероци од неговата работа или документација за поведена дисциплинска постапка. Во современата пракса оценувањето не се третира како застрашување на службеникот туку како начин на истиот 
да му се помогне да ја подобри својата работа, иди пак да се награди за доброто извршување на работите и работните задачи. Многу е важно како за менаџерот за човечки ресурси така и за работното место да се продуцира документација од оценувањето со подолг рок на чување во Секторот за човечки ресурси како лични документи на службеникот. Овие документи исто така треба да бидат заштитени и исклучиво достапни на најодговорните или на дица назначени од нив. Службеникот мора да има копија од конечната оценка односно од оваа документација. Вообичаена пракса е да се воспостави систем на менаџирање со извршувањето на работата и тоа најчесто составен од следните компоненти:

Аконтабилност на извршувањето - посебно е карактеристична за јавниот сектор и се однесува на тоа извршувањето на едно работно место да биде слично, не унифицирано но слично и препознатливо во сите демократски земји со слично демократско уредување.

Извршување преку повратна информација од корисниците на услуги, слично како давање цена на продуктот. Овде се изготвуваат индекси за оценување на услугите и тие се значаен индикатор и мерка за евентуална потреба за промена, со тоа што има три аспекти на мерење и тоа временска динија, пристапност и квалитет.

Ефикасно извршување кое се фокусира на внатрешната ефикасност од инпутот до аутпутот односно кога локалните први луѓе и советите донесуваат одлуки.

\section{Плати и надоместоци}

Под терминот плати се подразбираат: основните парични надоместоцุи за извриената работа (плати), покачуваната на платите и бонусите. Се одредени преку комплексни фактори што се карактеристика на организацијата. Истите се важен и ефективен мотивирачки фактор во изведбата на работните задачи и однесувањето на човечките ресурси во организацијата.

Пиатите во теоријата се наоѓаат како дел од компензациите за вложената работа, тие се во центарот на работните односи и се од критична важност како за работодавачите така и за работниците, во овој случај службениците. Вработените, најчесто својата егзистенција ја остваруваат токму со нив па затоа е нормално да дадат посебни залагања нивните примања да бидат поголеми.

Најчеста практика е организирањето на платите да биде во платни системи кои опфаќаат формат, ниво, структура и администрација на плаќањето.

Во однос на исплатата, најчест применет начин е исплатата да биде по извршената работа ${ }^{1}$, а притоа вработениот да ја прифати исплатата на наградата како личен напредок. Доколку му биде исплатена плата која не е

\footnotetext{
${ }^{1}$ Nevin, John (1999). "Analyzing Thorndike's Law of Effect: The Question of Stimulus - Response Bonds". Journal of the Experiment Analysis of Behaviour. p. 448.
} 
соодветна на квалитетот и квантитетот на неговата работа во иднина ефектот при работа на истиот работник ќе биде помал.

Нивото на платите е широк компаративен концепт за тоа како организацијата ги формира платите и кое е нивото во споредба со други слични организации.

Структурата на плаќањата најчесто е во согласност со хиерархијата на работни позиции и места во организацијата, коефициентите за категоризација на одговорноста, тежината, бараните вештини, работни часови (со фактор на ефективни работни часови), работното искуство, образованието, условите за работа и сл.

\section{ЗАКАУЧОК}

Менаџирањето со човечките ресурси е комплексна материја за која постои добра теоретска поддршка. Менаџирањето со човечките ресурси во последните две декади стана една од приоритетните области проследена со темелни реформи со цел ускладување со стандардите и нормите кои се применуваат во европскиот заеднички простор.

Во Република Северна Македонија има солидна законска основа за зајакнување на менаџирањето со човечките ресурси. Стратешкото планирање е метод кој е основа на менаџментот со човечки ресурси од регрутацијата, селекцијата, работните односи, мотивацијата, информирањето и комуникацијата, меѓусекторската соработка меѓу менаџерите на сектори и одделенијата, обуките како дел од развојните стратегии на организацијата, кариерата и менаџирањето со таленти, и секако тимската работа.

Поставувањето на пред сѐ, правилен пристап и однос кон менаџирањето со човечките ресурси заснован на научните теории дава одлична можност за зајакнувањето пред сѐ на раководните структури кои пак во многу вдијаат врз зајакнувањето на човечките ресурси. 


\section{Користена дитература}

"Performance Management Cycle". University of California, Berkeley, Center for Organizational and Workspace Effectoveness, https://dl.icdst.org/ pdfs/files/08dca929258df3c1ee9a1f7be2598405.pdf

Bach, S. and Edwards, R.M. (2012). Managing Human Resources: Human Resource Management in Transition. John Wiley \& Sons Ltd.

Nevin, J. (1999). “Analyzing Thorndike's Law of Effect: The Question of Stimulus - Response Bonds". Journal of the Experiment Analysis of Behaviour. p. 448.

Sherry E. M. \& Juan I. S. (2004), "Are your employees avoiding you? Managerial strategies for closing the feedback gap", Academy of Management Executive, Vol. 18, No. 1

www.oshr.nc.gov 
